\title{
SZEMPONTOK A TERÜLETI VERSENYKÉPESSÉG ÉRTELMEZÉSÉHEZ
}

\author{
(Considerations to the Interpretation of Regional \\ Competitiveness)
}

\section{PALKOVITS ISTVÁN}

Az üzleti szféra fogalmai, mint kereslet, verseny, piac, mindinkább polgárjogot nyernek a területekkel összefüggésben is. A nagyívü elméletek árnyékában azonban nem feltétlenül egyértelmü, hogy mit is értünk ezen általánosan használt kategóriák alatt: ezek vállalati/mikroökonómiai kategóriák-e avagy a „regionális makroökonómia" fogalmai. Jó példa erre, hogy a szakirodalomban, különösen pedig a területi menedzsment praktikus világában ma már közhelynek számító nézet az, hogy a régiók és városok versenyben állnak egymással (gyakran azzal az implicit következtetéssel, hogy e viszonyrendszer a fejlödés alakulásának legfontosabb körülménye). Ezzel kapcsolatosan is kevés az olyan publikáció, amely magának e versenynek a mibenlétét szabatosan definiálná, s e számos gondolatmenetnek alapjául szolgáló tételt szisztematikusan feldolgozná. Nem egyértelmü így az az alapvetỏ kérdés sem, hogy a piacok és a verseny milyen szinten értelmezendö, a régió egészére vonatkoztatható, vagy csak részpiacok léteznek és „összegződnek” a régió szintjén.

A verseny mint jelenség, az elemzések vagy fejlesztési stratégiák hátterében jellemzően egy-egy konkrét - egy vizsgált témát alátámasztó, vagy az éppen elemzett korszakot jellemző - megjelenési formája által képviselve jelenik meg, s csak nagy ritkán a maga komplexségében. Kétségtelen, hogy mindig voltak olyan funkciók, szolgáltatások, események vagy más (szükös) tényezők, melyek elömozdíthatták egyes területek, egyes területhez kötődő polgárok vagy érdekcsoportok céljait, és amelyek „elnyerése” verseny tárgyát képezhette. A hatalmi pozíciókért, gazdasági elönyökért, intézményekért folytatott városok közti verseny története a messzi múltba nyúlik, de míg korábban ez kisszámú szereplö közt dôlt el, ma a verseny(ek)ben való részvétel (különösen annak lehetösége) általánossá vált (Enyedi 1996). A verseny tartalma és feltételrendszere is más ma már: a korábbiaknál jóval inkább a - minden korábbit felülmúlóan a társadalmi lét szinte minden területére döntő hatást gyakorló - globális világgazdasághoz kötődik, és a gazdasági szereplök közvetlen érdekeivel, ezen keresztül pedig a területek gazdasági pozíciójával áll összefüggésben.

A megfelelő gazdasági pozíció eléréséhez különböző részcélok elérése, szükös és értékes dolgokból, jelenségekböl, tényezőkből a versenytársaknál több, vagy azoknak másoktól különbözö formában, minőségben történő birtoklása szükségeltetik. Ennek elérése lehet a versengés közvetlen célja. A versenykényszer oka természetesen a szúkösség (abszolút vagy minőségi): külsö fejlesztési források, cégek, in- 
formáció, értékes munkaerö, magas presztízsŭ (és befolyású) intézmények vagy lakosok stb. Mindezek léte meghatározó a helyi gazdasági teljesítmény(ek), a jövedelemszint (jóléti szint), ezáltal a helyiek elégedettsége, fokozódó identitástudata és cselekvő hajlama (és persze a politikusok újraválasztása) - mint a fejlesztés és a több síkon folyó verseny általános céljai - szempontjából. Ebben az összefüggésben a terïletek (és a területek szereplöi, aktorai) mint vásárlók (valamit megszerezni óhajtók) értelmezhetốk, ez tehát a területi verseny a keresleti oldalon.

A rendelkezésre álló erőforrások, adottságok felhasználása, összekapcsolása révén a terïletek (és a területek szereplöi, aktorai) kínálatot nyújtanak: lakóhelyet, befektetési környezetet, termékeket, szolgáltatásokat. E kínálat a piacon megmérettetik (a terïlettel és elemeivel szembeni kereslet tekintetében), a piaci verseny szelektál, s e szelekció eredménye döntően meghatározza az adott közösség céljainak megvalósulását, legkézenfekvőbb módon a képződö jövedelmet és létrejövő életszínvonalat.

A keresleti és a kínálati oldali versenypozíció egymással szorosan összefügg, a kettő együtt határozza meg a területek és a területek funkciói, szolgáltatásai, szereplöi, aktorai általános versenypozícióját, versenyben való eredményességét. (A dolgot bonyolítja, hogy a gazdasági szereplők egyfelól a területen belül egymással is versenyben állhatnak, s nemcsak azonos iparágakban, hanem egymástól teljesen eltérő tevékenységủek is, pl. telephelyért, munkaerỏért, másfelől az adott területen belüli szereplök piaci pozíciói nem függetlenek egymástól, dacára az elkülönült „verseny pályáknak”.)

$\mathrm{Az}$ egyes részpiacokon folyó verseny léte - közel állván a hagyományos mikroökonómiai fogalomhoz - viszonylag könnyen értelmezhetö. Ezzel szemben az „általános" verseny, általában a "területek versenye” absztraktságánál, származtatott jellegénél fogva jóval inkább misztikusnak hat, definiálása komoly elméleti kihívást jelent. A verseny e kevéssé köruilhatárolt fogalma mellett nem véletlen, hogy divergens elképzelések fogalmazódnak meg az annak terén tanúsított eredményesség operacionalizálását illetỏen is, számos kritérium, fogalom mentén próbálják értékelni egy régió versenypozícióját, gazdasági teljesítményét.

Mindezen megfontolások azt a következtetést sugallják, hogy a régiók versenye egy közkeletủen definiálatlan fogalom, amely mint - a régiómenedzsmentek aktivitását és a regionális politika decentralizációját elömozdítani kívánó - ideológiai fegyver meghaladja magyarázó erejét. Ennek háttere az, hogy nem a régiók versenyeznek, hanem a cégek (és a termékek, szolgáltatások), de a cégek versenyére a régióknak - a nemzeti kormányzatok rovására - mind nagyobb befolyásuk lesz (a decentralizációval, a vállalatok közti verseny jellegének megváltozásával, a stratégiai különbözőség szerepének felerősödésével stb.). Ez a piac-konform magatartásmintáknak - a régió-menedzsmentben valaha döntő súlyú bürokratikus szerepekhez képest - az elötérbe kerülésével azt a látszatot kelti, mintha a régiók közti verseny volna a döntö viszonyrendszer.

Ezzel szemben inkább konkrét versenyhelyzetek, egy-egy részterületre vonatkozó piacok léte tủnik relevánsnak, az általánosítás (az általában vett verseny) kevésbé. Ezekbe bizonyos piacszerü tevékenységeivel beavatkozhat, bizonyos piacokat be- 
folyásolhat egy régiómenedzsment: e tevékenysége (pl. régiómarketing) általában közjószágként értelmezhetỏ. E közjavak révén körvonalazódik a régió szerepe a vállalati versenyképességben, az ahhoz való hozzájárulás, amely funkció a területi menedzsment egyik föszerepe lehetne.

E ponton - a gazdasági szereplök versenyképességéhez történő hozzájárulásnál a gondolatmenet a vállalati stratégia témaköréhez „tévedt": annak trendjei megkerülhetetlen szempontok e kívánalomnak való megfeleléshez. Figyelembe kell venni, hogy a verseny természete mikroszinten is változó, az új versenyzési módokat követniük kell a területi menedzsmenteknek, vagyis a régióknak is. E témakör részletes kifejtése nélkül is indokoltnak tünik itt egy gondolat kiemelése a versennyel, annak jellegével összefüggésben.

A piacok és a verseny jellege változó: a lényeg ma már nem a stabil pozíciókból kiinduló direkt konfrontatív rivalizálás, hanem a verseny dinamikus, és az innováción illetve a stratégiai különbözöségek keresésén alapul (Porter 1998). Napjaink e terjedő, a verseny által megkövetelt vállalati magatartásmintáiból fakadóan a régiók versennyel kapcsolatos alapállása is változni kényszerül: a kooperativ megközelítés nem ritkán az egyetlen megoldás azokra a makacs problémákra, amelyeket a globalizáció, a „karcsúsitott” termelés (lean production) vagy a flexibilitás okoz (Asheim-Isaksen 1997).

A ,régiók versenye” kifejezésnek mindkét szava kérdőjeleket támaszt tehát: nemcsak hogy nem a régiók versenye az elsődleges, de a verseny, mint döntő (különösen pedig kizárólagos) elem elveszteni látszik korábban elsöprő erejünek hitt $\mathrm{e}$ szerepét. A verseny megítélése eszerint átalakulóban van: míg a régi elméletekben a tókéért folyó verseny játszik központi szerepet, addig az újakban a verseny alárendelödni látszik a kooperáció fogalmának, ami a partnerségtől a hálózatokig változatos formákat ölthet.

A verseny klasszikus fogalmával szemben az endogén fejlesztés koncepciója éppen azt fogalmazza meg, hogy nem egymás rovására történik az előnyszerzés, hanem önmagával, önmaga lehetöségeivel folytatja azt minden terület. Ehhez eszközöket kínál a decentralizáció a helyi közösségeknek: lehetőségeket a fejlesztésre, aktivitásra, a helyiek (cégek, lakosok) életéhez való pozitív hozzájárulásra, azok körülményeinek versenyképes alakulására. A régió nem közvetlenül versenyez, nem közvetlenül mérettetik meg, hanem gazdasági szereplöinek versenyképességén és (ez nem automatikus) lakosainak „versenyképes” életszínvonalán, elégedettségén keresztül.

A régiók, országok és városok életképességének (vagy más és más korokban az ezzel többé-kevésbé szinonimaként kezelt gazdasági teljesítményének vagy éppen versenypozíciójának) összevetése, minősítése régi igény, és máig meg nem oldott módszertani probléma. A régiók versenyének „felfedezésével” és a versenyképesség új kritériumának ezáltali felbukkanásával összefüggésben - akár a tudományos közleményeket, akár az Európai Unió dokumentumait tekintjük is - ma újból felélénkülni látszik e polémia. A napirenden szereplö különböző gyakorlatok és továbbfejlesztési törekvések szerteágazósága elsősorban az egyes módszerek komoly 
módszertani hiányosságaira vezethető vissza, de a vitát szükségképpen alapvetöen érintik az olyan elvi jellegü, értelmezésbeli különbségek is, mint a fenti, területi versennyel kapcsolatos eltérő álláspontok.

A nézetek sorában a legkézenfekvőbb elvi lehetőség az, hogy a régió versenyképességét egyértelmủen minősíti mérhetỏ gazdasági teljesítménye. Itt tehát a verseny egységes keretek között zajlik, a terület mint „,versenyzö”, „egy pont” gazdaságnak (,fekete doboznak") tekinthetö, s a verseny kritériuma egy konkrét mérőszám, statisztikai mutató (GDP, jövedelemszint), egy megfogalmazott célhoz kapcsolódóan. Ez nyilván leegyszerűsítő, számos kézenfekvő bírálattal illethető nézet: pl. a terület nem egységes egész, hanem egymással alkalmasint ütköző érdekekkel bíró érdekcsoportok halmaza; az aktuális jövedelemszintnél fontosabb annak hosszú távú alakulása; a lemaradók sem abszolút vesztesek, ezért a hatalom problematikája így nem megragadható, habár jelentősége egyébként döntő; a területi jövedelemnövekedés nem feltétlenül tükröződik a lakossági jólét emelkedésében stb. (Enyedi 1996). (Itt reprodukálható volna - a megoldás minden reménye nélkül - a makrokibocsátás mérésével kapcsolatos elvi és módszertani vita terjedelmes érvrendszere' ${ }^{\prime}$ ).

Mindazonáltal nemcsak elvi és módszertani okok miatt kell új mércéket, pozícióértékelési módokat keresni, hanem azért is, mert a világgazdaság fejlődésének természete mára alapvetỏen megváltozott, ,a fejlett piacgazdaságok regionális politikájában bekövetkezett paradigmaváltás fö jellemzője, hogy a tradicionális, növekedés-orientált regionális politikát új tényezőkre alapozott politika [...] váltja fel" (Horváth 1992). Míg korábban a fejlödés és fejlesztés célja világosan deklarálható volt (pl. a GDP szintjéhez kötve), ma csak nagyon általánosan lehet megfogalmazni a terület (közösség) gazdasági célját illetve a „verseny” tárgyát: elérendő a gazdasági aktivitás mennyiségi és minöségi jellemzöinek optimális szintje. Ennek operacionalizálását megoldani viszont igen ambiciózus vállalkozás.

Tekintettel a szempontok többszöröződésére és nem ritkán nehezen mérhető jellegére, a terület (mint egész) eredményességét „megmérni” vagy rangsorolni kívánó, de reálisabb álláspontot jelent az indikátorsorok, többdimenziós viszonyítások, „lágy" mutatók vagy kvalitatív módszerek alapján történő minősítés alkalmazása. $\mathrm{E}$ módszerek a mérhető teljesítmény helyett egy általánosabb eredményességet, kivívott pozíciót (esetleg sikerességet) vizsgálnak. Fontos kiemelni, hogy itt már a rangsorok és minősítések tükröznek számos részletet, strukturális és minőségi elemet, melyek figyelmen kívül hagyása egy rangsort megkérdőjelezhetővé tehet. A területi teljesítmények, pozíciók számbavételének ezen alternatív módjaira - a számos külföldi előzmény mellett - az utóbbi idószak hazai kutatásai is markáns példákat kínálnak.

Az első általános pozícióértékelési próbálkozásoknak a - módszertanilag sebezhetö - nemzetközi népszerüségi és versenylisták tekinthetők. Minőségi változást jelentett a matematikai eljárások elterjedése, a faktor- és klaszteranalízis, illetve a regresszióelemzés alkalmazása, majd az összetettebb módszerek, mint a többtényezös értékelés (multi-criteria evaluation, MCE) vagy a többdimenziós skálázás 
(multidimensional scaling, MDS). Ami a matematikai módszerek erőssége, az egyszersmind hiányosságuk is: a szükségszerü absztrakciók miatt óhatatlanul felmerül az egzaktság oltárán feláldozott információveszteség.

A formalizáltságban jelentős engedményeket téve, de az információk komplexebb megragadásának igényével lépnek fel a verseny gyözteseinek és veszteseinek azonosítására kialakult lágy módszerek, megközelítések. Ezek egyúttal - alkalmazóik részéröl - lényegében annak implicit elismerését is jelentik, hogy nem egységes a versenypálya, nincsenek egységesen követendỏ magatartások, nincs egységes mérce, s az egyedi elbírálások és értékelések is szükségesek a minösítéshez.

Sajátos, föleg az utóbbi évek hazai szakirodalmában használatos minösítö kritérium a siker, a régió vagy város sikeressége. A hazai átalakulás regionálisan szélsőséges lezajlása - a széleskörúen feltárt problémák kontrasztjaként látványos - pozitív jelenségeket is eredményezett. Ezeknek, mint „sikertörténeteknek” a dokumentálásának (Palkovits 1997), majd az esettanulmányok rendszerbe foglalásának (Rechnitzer 1998a) törekvései a kutatások markáns és perspektivikus vonalát jelentik napjainkban.

„A területrendszer sikere a gyorsabb alkalmazkodást jelenti. A rendszer, $\mathrm{s}$ annak alkotóinak többsége képes és alkalmas a politikai-gazdasági és társadalmi változásokat befogadni, azokat feldolgozni, majd reagálni egy vagy több adaptációs stratégia kidolgozásával illetve azok megvalósításával." (Rechnitzer 1998b) E meghatározás valójában siker-stratégiákról beszél, vagyis fejlesztési megközelitésböl indul ki, ami egyrészt az átmenet sajátosságaiból, másrészt a sikerpéldák, mintaterületek - a folyamatokra több ráhatást lehetövé tevő - kis „méretéböl” (kisvárosok, községek) vagy speciális helyzetéből (pl. közszféra tulajdonosi befolyása a gazdasági bázisra) adódik.

Nem véletlen, hogy e fogalom az átmenettel kapcsolatosan terjedt el: az esetek zömében egy radikális változáshoz való - szerteágazó okokra visszavezetett, de akár egy vissza nem térö lehetőségre reagáló rövid távú kihatású - alkalmazkodás, egy folyamat lezárulása képezi a vizsgálat tárgyát, így a sikeresség a régió ex post, a jövő esélyeiről keveset mondó minősítése.

Mindazonáltal a „sikeres” területek hazai és nemzetközi példáinak hasonlóságai lehetöséget nyújtanak bizonyos általános következtetések levonására (többékevésbé teljes, illetve többé-kevésbé önkényes irányelvek megfogalmazására), melyek különösen a fejlesztés gyakorlatában nyerhetnek jelentöséget. Kiváló példa erre Enyedi - méltán sokat hivatkozott - sikeres városok ismérveit tartalmazó listája (Enyedi 1997), mely számos fontos, nemegyszer a gazdaságon túlmutató, gyakorlatban különösen nagy segítséget nyújtó szempontra hívja fel a figyelmet. Ugyanakkor minden lista és etalon kizárólagosságával és általános érvényességével szemben kétségek támaszthatók, mivel jelentős különbség lehet a régiók (városok) között (jellegükben, funkcióikban).

A régiók minösítésének viszonylag új törekvése a versenyképesség meghatározása, mely fogalom - a radikális (rendszer)váltásoktól mentes fejlett világban bukkanván fel - a versenypozició hosszabb időhorizontú megítélés kísérletét te- 
kint(het)i céljának. A fogalom - ugyancsak vállalati szféra mintájára történő - felmerülése a területekkel kapcsolatban egyenes következménye a „verseny” gondolatának elterjedésével, egyúttal azonban magán viseli az azzal kapcsolatos fogalmi tisztázatlanságokat is.

A versenyképesség mibenlétét illetően legmarkánsabb álláspontot annak elvetése képezi. Ennek egy példája Krugman - csak a vállalati versenyt elismeró - álláspontja: mint cikkének címe is kiemeli, a versenyképesség egy „veszélyes rögeszme" (Krugman 1994). Ide illeszthető Porter nézete is, aki a régiókkal összefüggésben tanulmányaiban gondosan kerüli a kifejezés alkalmazását: öt csak bizonyos területhez kötődő jellemzők, kiaknázható kompetitiv elönyök érdeklik gondolatmenetében (nemzeti szinten a termelékenységgel azonosítja e fogalom tartalmát) (Porter 1998).

A „versenyképesség” fogalom mindazonáltal elterjedt, jószerével minden ezzel kapcsolatos tanulmány tartalmaz egy önálló, saját értelmezést tükröző definíciót ${ }^{2}$, melyek listázása szinte lehetetlen. Az ezek rendszerezésére tett egyik kísérlet szerint - a fogalom relevanciáját, meghatározhatóságát elismerők körében - három markáns nézetcsoport azonosítható. A „gyakorlatias” felfogás szerint a versenyképesség a cégek adaptálási képességét jelenti, hogyan tudják a máshol sikeres technikai és szervezeti megoldásokat átvenni. A „környezeti/rendszer" felfogás szerint a versenyképesség azt jelenti, hogy a vállalat hogyan tudja optimalizálni gazdasági környezetének, azaz gazdasági bázisának elemeit (tőke- és munkapiac, inputok minősége, infrastruktúra). A „tőke-fejlesztés" felfogás szerint a versenyképesség azt jelenti, hogyan tudja egy vállalat vagy ágazat akkumulálni a humán és fizikai tőkét, a technológiát. Egy régió vagy ország akkor versenyképes, ha vonzza a befektetéseket (Lengyel 1999).

A fenti kategóriákhoz tartozó területi versenyképesség-fogalmak, $\mathrm{s}$ az azok ötvözeteként megfogalmazott számos $\mathrm{OECD}, \mathrm{EU}^{3}$ és egyéb definíció zöme - az információsủrítés követelményéből fakadó leegyszerủsítések mellett - magán viseli az említett csoportképző megfogalmazásokban fellelhető problémák valamelyikét: a „gyakorlatias" álláspontokban kiemelt „legjobb megoldások” alkalmazása csak követő, semmint versenyképes magatartást tesz lehetővé, a "környezeti/rendszer" megközelítés kulcselemeinek, a gazdasági bázisnak és az optimalizálásnak a középpontba állítása a rendszer dinamikájával kapcsolatos igénnyel (beleértve a faktorteremtés elvét is) tünik némiképp ellentétesnek, míg a „töke-fejlesztés” felfogások elsősorban a mennyiségi elemek túlzott hangsúlyozása illetve az endogén elemek negligálása miatt bírálhatók.

Pozitív oldalról közelítve: néhány alapvetö momentum, melyek feltétlenül számításba veendők a területek versenypozíciójának minősítésénél. Ilyenek:

- a régió nyitottsága, a gazdasági szereplők nemzetközi piacokon való megmérettetése, azok kedvezö versenypozíciójának (nem pusztán az exportvolumen, hanem a nehezen másolható magas szintủ általános termelési képesség, az ennek alárendelt termelékenység, szervezeti tanulási képesség, piaci részesedés, 
rugalmasság, innovációs készség, új termék piacraviteli gyorsasága és számos más téren egyidejüleg megnyilvánuló) tartóssága, megalapozottsága;

- a tudás-intenzív tevékenységek nagy súlya, ezzel összefüggésben a régióbeli lakosság jövedelmeinek magas általános szintje;

- a gazdasági szereplők stratégiai érdekeltsége a helyben maradásra, vagyis azok regionális/lokális beágyazottsága ( gazdálkodási, vagyis nem elsősorban tulajdonosi);

Ugyan rendkívül fontos cél, de - az elterjedt nézettel ellentétben - nem feltétlenül központi eleme, feltétele, inkább eredménye a (gazdasági értelemben vett) versenyképességnek a magas foglalkoztatási szint. A lakosság bizonyos csoportjai minden ez ellen ható közösségi eröfeszités ellenére - akár önhibájukból, akár nem - kiszorulhatnak a versenyszférán belüli foglalkoztatásból, s ez önmagában nem zárja ki a versenyképesség érvényesülését. Egy, a fenti követelményeknek megfelelő gazdasági bázis egyfelöl nagy valószínúséggel megfelelően nagy és bővülö számú képzett és motivált munkaeröt igényel, másfelöl megteremti az alapját a szociális szempontok érvényre jutásának.

A felsorolt szükséges momentumok egy mondatba sủrítése - különösen az első elem fontos alkotórészeinek elsikkadása által - általánosságként hangozhat, minden elemének komplex megragadása viszont meghaladja a definíciók szokásos terjedelmét. E korlátok tudatában, valamint ha elfogadjuk a régiók versenyképessége egy megfelelően tág fogalmának relevanciáját, akkor annak meghatározása így hangozhat: versenyképes egy régió, ha stratégiailag beágyazott gazdasági bázisa piaci értékén megvásárolva optimálisan felhasználja és generálja (bövitett ủjratermelödésre ösztönzi) a régió magasrendü eröforrásait, miközben tartós versenyképességet ér el a releváns nemzetközi piacokon ${ }^{4}$.

A versenypozíció-értékelés fentiekben körvonalazott megközelítése tartalmát illetően eltér a legelterjedtebb versenyképesség-nézetektöl, másfelöl annak egy mindezen elemeket magában foglaló koncepciója a versennyel kapcsolatosan összhangban levőnek tünik a fentiekben megfogalmazott elképzeléssel.

A meghatározás egyik eleme, a vállalkozások versenyképességének középpontba állítása a hazai irodalomban sem új: erre utal Horváth is, aki szerint a regionális versenyképesség „nem más, mint a termékek és szolgáltatások értékesítési képességének javulása a nyílt versenypiacokon" (Horváth 1998). A másik elemnek, a vállalati és regionális pozíciók összekapcsolásának hátterében annak a tételnek az elfogadása áll, hogy a vállalatok versenyképessége nemcsak belső tényezökön múlik, hanem a külső, regionális és lokális feltételrendszer, társadalom- és gazdaságföldrajzi környezet által is befolyásolt. A tér, amely a gazdasági tevékenységeket befolyásolja egy sajátos eröforrás a gazdasági szereplök számára, s ennek minősége abban nyilvánul meg, hogy milyen értékes erőforrás, mennyiben tud hozzájárulni a vállalati célok (vállalati versenyképesség) kedvező alakulásához.

Ami az első elemet, a gazdasági bázis versenyképességét mint minősítő ismérvet illeti, annak operacionalizálása - különösen pedig a korábbiakban áttekintett teljesítménymutatóknak megfeleltetése - megoldatlan probléma. A kvázi-megoldások 
kapcsán a kielégítő „regionális makromutatók” keresése helyett - különös tekintettel a minőségi és strukturális elemek döntô jelentőségére - a mikroszféra alapulvétele tünik célravezetőnek. A fenti logikának leginkább megfelelö eljárás szerint elvileg a gazdasági bázis vállalati szinten megragadott, valamilyen szempont szerint aggregált, általánositott jellemzői alapján tipizálhatók és minösithetök (pl. versenyképesnek) a regionális gazdaságok.

E módszerre kínál példát az alábbi gondolatmenet, melynek kiindulópontja egy széles körủ kutatás eredménye (Miller-Roth 1994), a vizsgálatba bevont vállalkozásoknak számos ismérv szerinti elemzése alapján történt egyfajta minöségi kategórizálása ${ }^{6}$.

A szerzők tizenegy vállalati kompetitív képesség (alacsony ár, dizájn-flexibilitás, volumen-flexibilitás, minőség-állandóság, teljesítmény, gyorsaság, megbízhatóság, eladás utáni szolgáltatások, reklám, széles disztribúció, széles termékskála) ${ }^{7}$ alapján 164 amerikai feldolgozó-ipari nagyüzemet kategorizáltak (klaszteranalízis segítségével), és soroltak három élesen elkülöníthető csoportba. E csoportokban - melyek a létező iparági hatások ellenére ,ágazatilag vegyesnek" bizonyultak - két dimenzió mentén különböznek a vállalatok: egyik a cég képessége saját maga megkülönböztetésére, a másik pedig termékskálájának és piacainak kiterjedése. A karakteresen elkülönülö csoportok - jellemző jegyeik alapján, szabad fordításban - a „középszerüek”, a „piac-szemléletủek” illetve az ,innovătorok” neveket kapták ${ }^{8}$.

A gondolatmenet fonalát folytatva a vizsgálat ezen eredményének értelmezhető térbeli vetülete is: az egyes kategóriák relatív súlya egy-egy régió gazdaságában meghatározhatja a régió karakterét. Eszerint tipizálhatjuk a területeket, és minösithetjük azokat - a megnevezett kategóriákhoz kötődően sorrendben - mondjuk „stagnálónak”, „alkalmazkodóképesnek” vagy „innováció-gazdagnak” (nem is szólva a nem ,tiszta" típusokról). Ezen kategóriák - nem mint a faktoranalízis eredménye, hanem mint azok interpretációi - a „versenyképesség" tekintetében egyfajta ,lágy” rangsort is alkothatnak. (Tekintettel arra, hogy e hivatkozott kutatás célja nem a jelen összefüggésben történő alkalmazás volt, itt e gondolatmenet csak mintaként szerepelhet. Egy célirányos, a régiókat reprezentáló mintán elvégzett kutatás akár releváns eredményekhez illetve a módszer igazolásához is vezethet.)

A másik elem, a vállalati és regionális pozíciók összekapcsolása azt a kérdést veti fel, hogy a régió e jellemzői (e karaktere) mennyiben egy tértöl lényegében független vállalati kör szinte „,véletlenszerú” földrajzi vetülete, vagyis mennyiben tulajdonítható ez be a régiónak, annak sajátosságainak, ahhoz maga a régió hozzájárul-e.

Ha a régiót mint sajátos önálló entitást (a szereplőinek keretet, feltételrendszert nyújtó társadalomföldrajzi fogalmat) nézzük, elvonatkoztatva az adott idópontban mủködő gazdasági entitásoktól, akkor a versenyképesség fogalma nem értelmezhető. Ekkor e „régió” lehetöségeit az határozza meg, hogy saját belső adottságai, jellemzői által képes-e tartósan hozzájárulni a területén egyébként működő versenyképes vállalkozások folyamataihoz.

A hagyományos gazdasági elméletnek a területi versenyképesség megértésében tapasztalható eszköztelenségét elismerő, a mikroszintröl induló elemzést elötérbe 
helyező szemléletváltás jó gyakorlati példája egy, a MIT Commission on Industrial Productivity által készített, az USA versenyképességét elemző tanulmány. Ez már nem a szokásos kategóriákat (valutaárfolyamok, fajlagos munkaerőköltségek, kereskedelmi megállapodások, „gazdasági környezet” faktorok) vizsgálja célja elérése érdekében, hanem „,bottom-up” megközelítésben a nemzet termelési rendszerét: a szervezeteket, az üzemeket, a berendezéseket és az embereket a gyári munkástól a felsőszintü vezetöig, melyek együtt kigondolják, megtervezik, kifejlesztik, előállítják, piacra viszik és kiszállítják a termékeket és szolgáltatásokat a fogyasztók számára. A mérce tehát nem a hagyományosan mért produktivitás, hanem a MIT bizottság kifejezésével élve, a produktivitási teljesítmény (productivity performance) (Begg 1994). Mindezen elemek minősége viszont ezer szállal kötődik a területhez, társadalmi-gazdasági-kulturális térhez, annak szerepe ezek alakulásában nem megkérdöjelezhetö.

Mindezen megfontolások - mint a verseny jellege, a ,versenyképesség” tartalma, a mikroszféra központi szerepe - alapján komoly dilemmákat ébreszt magának a „versenyképesség” fogalomnak a régiók esetében történő használatának kérdése is. Habár a régiók versenyképessége mint fogalom elterjedt és számos fontos elvet ${ }^{9}$ visszatükröz, a kifejtett szempontok pontosabb megragadása érdekében alternatívák keresése indokoltnak - ha gyakorlatilag reálisnak nem is - tủnik. Ilyen lehet például a produktivitási potenciál (tartalmilag pontosabban, de körülményesebb megfogalmazásban ,versenyképesség-forrás készlet”), ami egyfelöl a nem statikus jellegre, másfelöl a vállalati produktivitással való összefüggésre is utal. Az ezzel szinonimaként értelmezett, tág értelemben használt versenyképesség-fogalom (mint kompromisszum) tartalmilag tehát hangsúlyozottan nem egy teljesítmény-mérce, vagy összehasonlítható általános mutató, hanem önmagában egyedileg lágy módszerekkel, illetve elemeiben a releváns versenytársakkal összevetve értékelendö; s a régiók versenyképessége ebben az értelemben a magas produktivitási potenciálnak felel meg.

\section{Jegyzetek}

${ }^{1}$ Címszavakban: pénzbeli vs. nem pénzbeli mutatók; a számbaveheobség korlátai; a tevékenységek társadalmasítottsága; területi vs. állampolgársági elv; bruttó vs. nettó; tényleges vs. potenciális szint; termelés vs. fejlettség; fogyasztás vs. jólét; egy mutató vs. több; piac által „,be nem árazott" dolgok kérdése; jövedelemmutatók tartalmi alternatívái stb.

${ }^{2}$ Megjegyzést érdemel, hogy a hazai regionális irodalom eddig lényegében kimaradt e sorból.

${ }^{3}$ A definíciók sorából - kevésbé tudományos, inkább ,aktuális" szempontból - kiemelve az Európai Unió ma „hivatalos” álláspontját, illusztrálható a megfogalmazások általánossága, a birálati leheobségek általában tág tere. Eszerint a versenyképesség: vállalatok, iparágak, régiók, nemzetek és nemzetek feletti régiók képessége viszonylag magas jövedelemszint és foglalkoztatás generálására a nemzetközi piacoknak való „,kitettség" mellet (Moqué 1999).

4 A definíció implicit módon tartalmazza a magas regionális GDP-t, az innovációs készséget, a magas termelékenységet és számos más, az elterjedt definíciókban megjelem̋ elemet is.

${ }^{5}$ A forrásban kiemelés nélkül.

${ }^{6}$ A kategorizálás természetesen más elvek alapján is történhetne (alternatívaként szóba jöhet akár a termékéletgörbe elmélet alapján történő gondolkodás is).

${ }^{7}$ A lista nem tekinthetô önkényesnek, abból a szempontból, hogy eősen támaszkodik a kutatási elözményekre: a lista első nyolc eleme igen hasonló a többi hasonló munka javaslataihoz (a leggyakrabban 
kiemelt kompetitív képességek a minöség, a költség /hatékonyság, szállítás/, a reagálóképesség, a flexibilitás, az innováció és a fogyaszrói szolgáltatások), csupán az utolsó három tekinthetỏ a kutatás sajắtos szempontjait és a szerzők egyéni megítélését tükrözőnek.

${ }^{8}$ A „középszerủek" kevés hangsúlyt helyeznek a kompetitiv képességek kifejlesztésére, ami csupán a versenyben maradás minimális követelményeire tesziőket alkalmassá; a legnagyobb csoportot képezo „piac-központúak" a piaccal kapcsolatos kompetitiv képességek terén eósek, de feltehetöen nem ök diktálják a verseny feltételeit és tempóját; az „innovátorok” nagyobb dizăjn-flexibilitás és gyorsabb új termék piacravitel révén egy lépéssel versenytársaik eb̆tt járhatnak.

${ }^{9}$ A versenyképesség szó használata melletti érvek (elfogadhatóságának indokai): egyrészt utal a versenykörnyezetre, s ez annak ellenére fontos, hogy - a fent kifejtett álláspont szerint - nem a régiók kỡzvetlen versenye a döntő; másrészt utal a hosszabb távra tekintés, a fenntarthatóság szükségességére.

\section{Irodalom}

Asheim, B.T.-Isaksen, A. (1997) Localisation, agglomeration and innovation: towards regional innovation systems in Norvay? - European Planning Studies. 5. 299-330. o.

Begg, I. (1994) The case for decentralized industrial policy. European Challenges and Hungarian Responses in Regional Policy. - Hajdú Z.-Horváth Gy. (szerk.), Pécs, MTA RKK. 193-210. o.

Enyedi Gy. (1996) Regionális folyamatok Magyarorszagon. Budapest, Hilscher Rezsỏ Szociálpolitikai Egyesület.

Enyedi Gy. (1997) A sikeres város. - Tér és Társadalom. 4. 1-7.o.

Horváth Gy. (1992) A magyar regionális politika súlypontjai. - Tér és Társadalom. 1-2. 1-15. o.

Horváth Gy. (1998) Európai regionális politika. Budapest-Pécs, Dialóg Campus Kiadó.

Krugman, P. (1994) Competitiveness: a dangerous obsession. - Foreign Affairs. 74(2). 28-44. 0.

Lengyel I. (1999) Régiók versenyképessége. (A térségek gazdaságfejlesztésének fobb közgazdasági fogalmai, alapgondolatai, tényezői az EU-ban). Szeged, JATE Regionális és Alkalmazott Gazdaságtani Tanszék. Múhelytanulmány kézirata.

Miller, J.G.-Roth, A.V. (1994) A Taxonomy of Manufacturing Strategies. - Management Science. March. 285-302. o.

Moqué, D. (ed.) (1999) Sixth Periodic Report on thte Social and Economic Situation and Development of Regions in the European Union. Brisszel, European Commission.

Palkovits I. (1997) Sikeres vállalatok - sikeres település: Szentgotthárd. - Tér és Társadalom. 4. 69-85. o.

Porter, M. (1998) Clusters and the New Economics of Competition. - Harvard Business Review. Nov.-Dec.

Rechnitzer J. (1998a) Területi stratégiák. Budapest-Pécs, Dialóg Campus Kiadó.

Rechnitzer J. (1998b) Az átmenet a területi gazdaságban és a siker. Munkaeröpiac és regionalitás az átmenet időszakában. - Fazekas K. (szerk.), Budapest, MTA KTI. 113-145. o.

\section{CONSIDERATIONS TO THE INTERPRETATION OF REGIONAL COMPETITIVENESS}

\section{ISTVÁN PALKOVITS}

Competitiveness is nowadays a more and more widely used term concerning the evaluation of regions, with a commonplace but barely analysed proposition (i.e. regions and cities are in competition) in the background. Although several „official" definitions of the term exist, the serious doubts regarding its content account for the continuous reconsideration.

The paper argues for the microeconomic-approach interpretation of regional competition and competitiveness. The criteria of the competitiveness of regions are twofold: what are the competitive positions of the local actors in the global markets like, and to what extent can the locality (as a special asset) contribute to their competitiveness. In this sense of the notion, regional competitiveness can not be properly qualified on the basis of the usual ex-post indices of the 'regional macroeconomy', it should be studied with new methods placing microsphere into the limelight. 